\title{
Surfactant protein $D$ in serum from patients with allergic bronchopulmonary aspergillosis
}

\author{
M. Krane, M. Griese
}

Surfactant protein $D$ in serum from patients with allergic bronchopulmonary aspergillosis. M. Krane, M. Griese. (C) ERS Journals Ltd 2003.

ABSTRACT: Surfactant protein D (SP-D) interacts with Aspergillus fumigatus and is strongly increased in the lavage from animals with acute allergic reactions to the fungus, suggesting a central role for SP-D. As the course of cystic fibrosis (CF) is often complicated by an allergic bronchopulmonary aspergillosis (ABPA), the authors hypothesised that SP-D may also be increased in serum during an ABPA, potentially assisting in its diagnosis and follow-up.

In 22 patients with CF (11 with ABPA, 11 matched without ABPA) and 19 control patients without a pulmonary disease, SP-D concentrations in serum were assessed by an enzyme immunoassay.

Serum SP-D in CF patients $\left(130 \pm 16 \mathrm{ng} \cdot \mathrm{mL}^{-1}\right.$ (mean \pm SEM)) was significantly higher than in the controls without lung disease $\left(66 \pm 8 \mathrm{ng} \cdot \mathrm{mL}^{-1}\right)$. During the whole ABPAepisode, SP-D level did not change significantly, despite large changes of total serum immunoglobulin $\mathrm{E}$. There was a clear negative correlation between SP-D concentration and overall lung function, i.e. forced expiratory volume in one second and forced vital capacity.

Serum level of surfactant protein D may be of value to follow pulmonary function and lung injury in cystic fibrosis patients. Surfactant protein D serum levels are not helpful for the diagnosis and follow-up of an allergic bronchopulmonary aspergillosis episode, contrary to what was expected from animal experiments.

Eur Respir J 2003; 22: 592-595.
Children's Hospital, Ludwig Maximilians University of Munich, Munich, Germany.

Correspondence: M. Griese

Children's Hospital

Dr. von Hauner Kinderspital

Lindwurmstr. 4

D-80337 München

Germany

Fax: 498951607872

E-mail: mgriese@helios.med.uni-muenchen.de

Keywords: Allergic bronchopulmonary aspergillosis

cystic fibrosis

surfactant protein $\mathrm{D}$

Received: May 302003

Accepted: June 222003
Allergic bronchopulmonary aspergillosis (ABPA) is a pulmonary hypersensitivity disease caused by a reaction to chronic colonisation of the airways with Aspergillus fumigatus [1]. It is frequently observed in patients with cystic fibrosis (CF) $(10 \%)$ and less frequently in bronchial asthma $(\sim 1 \%)$ $[1,2]$. The pathogenesis of the ABPA is not entirely clear, however the antigen-specific T-helper cell type 2 response with an increased interleukin (IL)-4 and IL-5 production may play an important role [3]. This, and an increased sensitivity to IL-4 in patients with ABPA [4], leads to highly elevated immunoglobulin (Ig)E levels and eosinophilia.

Surfactant protein D (SP-D) is involved in the innate respiratory response to many different bacteria, fungi and viruses. It directly interacts with these microorganisms and plays an important role in the regulation of the pulmonary host defence through direct or indirect interactions with immune effector cells [5]. In general, the synthesis and secretion of SP-D increase in association with lung injury and activation of the respiratory epithelium [5]. For example, levels of SP-D messenger ribonucleic acid and SP-D accumulation are increased within 24-72 h after intratracheal instillation of lipopolysaccharide (LPS) in rats and by challenge with Pseudomonas aeruginosa in mice [5]. In addition, the levels of SP-D can increase markedly in response to the overexpression of IL-4 [5].

Current investigations also point to the important role of SP-D in the pathogenesis of ABPA. MADAN et al. [6] showed that SP-D can block the specific binding of IgE to A. fumigatus antigens. This blockade of $A$. fumigatus allergen is mediated through the carbohydrate recognition domain of
SP-D. The binding of SP-D to A. fumigatus enhances their phagocytosis by human neutrophils and alveolar macrophages [7] and SP-D is protective against pulmonary hypersensitivity induced by A. fumigatus antigens in mice [8]. During an $A$. fumigatus -induced allergic airway inflammation in BALB/c mice, the lavage levels of SP-D were increased nine-fold [9]. The increased SP-D levels were positively correlated with the total IgE level in serum [9]. Therefore, the authors hypothesised that serum SP-D may assist in the clinical diagnosis and management of ABPA in patients with CF and investigated SP-D level in serum during episodes of ABPA.

\section{Methods}

\section{Patients}

A total of 41 patients were included in the study. Altogether, 11 patients with CF and ABPA and 11 matched $\mathrm{CF}$ patients without ABPA were selected from the $\mathrm{CF}$ outpatient clinic at the Kinderpoliklinik of the Dr. von Hauner Kinderspital, serving 155 paediatric and adult patients with $\mathrm{CF}$. The patients with $\mathrm{CF}$ and ABPA had an average age of $19.6 \pm 2$ yrs (mean \pm SEM; range $11-31$ ). These patients experienced an acute episode of an ABPA between 1999-2001. The diagnosis of ABPA was based on a minimum of six, or five plus eosinophilia, of seven criteria described by NELSON et al. [10] including: wheezing, pulmonary infiltrates, 
Table 1.-Patients with cystic fibrosis and allergic bronchopulmonary aspergillosis

\begin{tabular}{|c|c|c|c|c|c|c|c|c|c|c|}
\hline $\begin{array}{l}\text { Patient } \\
\text { number }\end{array}$ & $\begin{array}{l}\text { Age } \\
\text { yrs }\end{array}$ & Sex & Wheezing & $\begin{array}{c}\text { Pulmonary } \\
\text { infiltrate }\end{array}$ & $\begin{array}{l}\text { A. fumigatus } \\
\text { in sputum }\end{array}$ & $\begin{array}{l}\text { Skin-prick } \\
\text { test against } \\
\text { A. fumigatus }\end{array}$ & $\begin{array}{l}\text { Total IgE } \\
\text { IU } \cdot \mathrm{mL}^{-1}\end{array}$ & $\begin{array}{c}\text { IgE } \\
\text { against } \\
\text { A. fumigatus } \\
\text { RAST* }\end{array}$ & $\begin{array}{c}\mathrm{IgG} \\
\text { against } \\
\text { A. fumigatus } \\
\mathrm{EU} \cdot \mathrm{mL}^{-1 \#}\end{array}$ & $\begin{array}{c}\text { Blood } \\
\text { differential } \\
\text { cell count } \\
\% \text { eosinophils }\end{array}$ \\
\hline 1 & 16 & $\mathrm{~F}$ & + & + & + & + & 714 & 2 & 588 & ND \\
\hline 2 & 11 & $\mathrm{~F}$ & + & - & + & + & 6178 & 2 & 1337 & 8 \\
\hline 3 & 27 & M & - & + & + & + & 6606 & 2 & 221 & ND \\
\hline 4 & 13 & $\mathrm{~F}$ & + & + & + & + & 1817 & 2 & 524 & 20 \\
\hline 5 & 25 & M & + & + & + & + & 4159 & 1 & 257 & 5 \\
\hline 6 & 23 & $\mathrm{~F}$ & + & + & + & - & 5337 & 2 & 576 & 8 \\
\hline 7 & 22 & M & + & + & + & + & 4895 & 3 & 172 & ND \\
\hline 8 & 31 & M & + & + & + & + & 3601 & 1 & 28 & 11 \\
\hline 9 & 19 & $\mathrm{~F}$ & + & + & + & + & 929 & 1 & 678 & 11 \\
\hline 10 & 16 & M & + & - & + & + & 535 & 0 & 1530 & 6 \\
\hline 11 & 13 & M & - & + & + & + & 3830 & 2 & 369 & 17 \\
\hline $\begin{array}{l}\text { Mean } \pm \text { SEM or } \\
\text { fraction of } \\
\text { passed criteria }\end{array}$ & $19.6 \pm 2$ & $6 \mathrm{M} / 5 \mathrm{~F}$ & $9 / 11$ & $9 / 11$ & $11 / 11$ & $11 / 11$ & $3509 \pm 665$ & $10 / 11$ & $571 \pm 1$ & $8 / 11$ \\
\hline
\end{tabular}

F: female; M: male; A. fumigatus: Aspergillus fumigatus; IgE: immunoglobulin E; RAST: radioallergosorbent test; IgG: immunoglobulin G; ND: no data. +: positive; -: negative. *: $0=$ nondetectable, $1=$ low, $2=$ moderate, $3=$ high; ${ }^{\#}$ : normal up to $40 \mathrm{Eu} \cdot \mathrm{mL}^{-1}$.

A. fumigatus in sputum, positive skin-prick test for $A$. fumigatus, increased total $\mathrm{IgE}$, increased specific $\mathrm{IgE}$ and $\mathrm{IgG}$ against $A$. fumigatus (table 1). Antibiotic and anti-inflammatory medication before the episode of ABPA was as follows: oral antibiotics (cefuroxime, trimethoprim-sulfamethoxazole): $7 / 11$; inhaled tobramycin: 6/11; and inhaled glucocorticosteroids: 7/11. One patient (aged $31 \mathrm{yrs}, 82 \mathrm{~kg}$, male) took systemic steroids (4 mg prednisolone on alternate days for several years) and another (aged $22 \mathrm{yrs}, 65 \mathrm{~kg}$, female) took itraconazole $(2 \times 100 \mathrm{mg}$ daily) for $>1 \mathrm{yr}$. The patients with $\mathrm{CF}$ but without ABPA were matched to the previous group by sex, age, disease severity and weight for height (mean age of 19.0 \pm 2.4 , range 9-36). Their antibiotic and anti-inflammatory medication did not differ significantly from that of the group with ABPA: oral antibiotics (cefuroxime, trimethoprimsulfamethoxazole): 6/11; inhaled tobramycin: 6/11; inhaled steroids: $6 / 11$; and systemic steroids: $0 / 11$. None of these patients had a specific sensitisation against $A$. fumigatus as assessed by specific IgE and skin-prick test. The patients were in a stable clinical condition without any signs for a pulmonary exacerbation. The average forced expiratory volume in one second (FEV1) was $79.6 \%$ (range 33-112\%). The pathogens recovered from the respiratory secretions were similar in this group without ABPA and the group with APBA (Pseudomonas aeruginosa: 6/11 and 7/11; Staphylococcus aureus: $7 / 11$ and 4/11; Stenotrophomonas maltophilia: 1/11 and 2/11; Burkholderia cepacia: $1 / 11$ and 0/11; and Candida albicans: $3 / 11$ and 3/11). The non-CF/disease control group consisted of six female and 13 male patients with an average age of $8.7 \pm 1$ yrs (range 2-17). These patients were recruited from the general outpatient dept and were free of any acute or chronic pulmonary disease. There were no signs for an inflammatory reaction as assessed by history and C-reactive protein and white blood cell count and differential haemogram. Serum from all subjects was obtained after informed consent. The study protocol was approved by the institutional review board.

\section{Study-design}

All patients with $\mathrm{CF}$ were routinely and prospectively monitored for the presence of ABPA by the clinical and serological criteria. During the period of time for an ABPA episode the maximum of total serum IgE was accepted as the peak of this ABPA episode and set to $100 \%$. The SP-D concentration was measurerd during the time period 16 weeks before and 16 weeks after the maximum of serum IgE. In both comparison groups all variables were assessed at one point in time.

\section{Measurement of surfactant protein D in serum}

The concentration of SP-D in serum was assessed with an established enzyme-linked-immunosorbent-assay validated for measurements in serum (Yamasa Corporation, Choshicity, Japan) [11].

\section{Statistics}

Differences between independent groups were assessed by analysis of variance, followed by Newman-Keuls multiple comparison test. A change was considered significant when the $\mathrm{p}$-value was $<0.05$. Results are given as means \pm SEM.

\section{Results}

During the course of an ABPA-episode the IgE concentration increased on average by a factor of two from the time before the ABPA to the peak of the episode (fig. 1). Thereafter and with treatment, i.e. oral corticosteroids $\left(2 \mathrm{mg} \cdot \mathrm{kg}^{-1} \cdot \mathrm{d}^{-1}\right.$ over 10-15 days) and oral itraconazole for several weeks, IgE decreased to near the pretreatment level of the time before ABPA. FEV1 dropped slightly during the course of ABPA and was somewhat increased with treatment with oral corticosteroids and itraconazol. However, these changes were not statistically significant.

SP-D was assessed in the same serum samples during the course of the ABPA-episodes (fig. 2). There were no significant changes of the SP-D concentrations with time. SP-D also did not correlate with total serum IgE. However, serum SP-D was inversely correlated to the lung function in CFpatients with ABPA (fig. 3). A higher serum SP-D concentration was associated with lower level of FEV1 and forced vital capacity (FVC). 

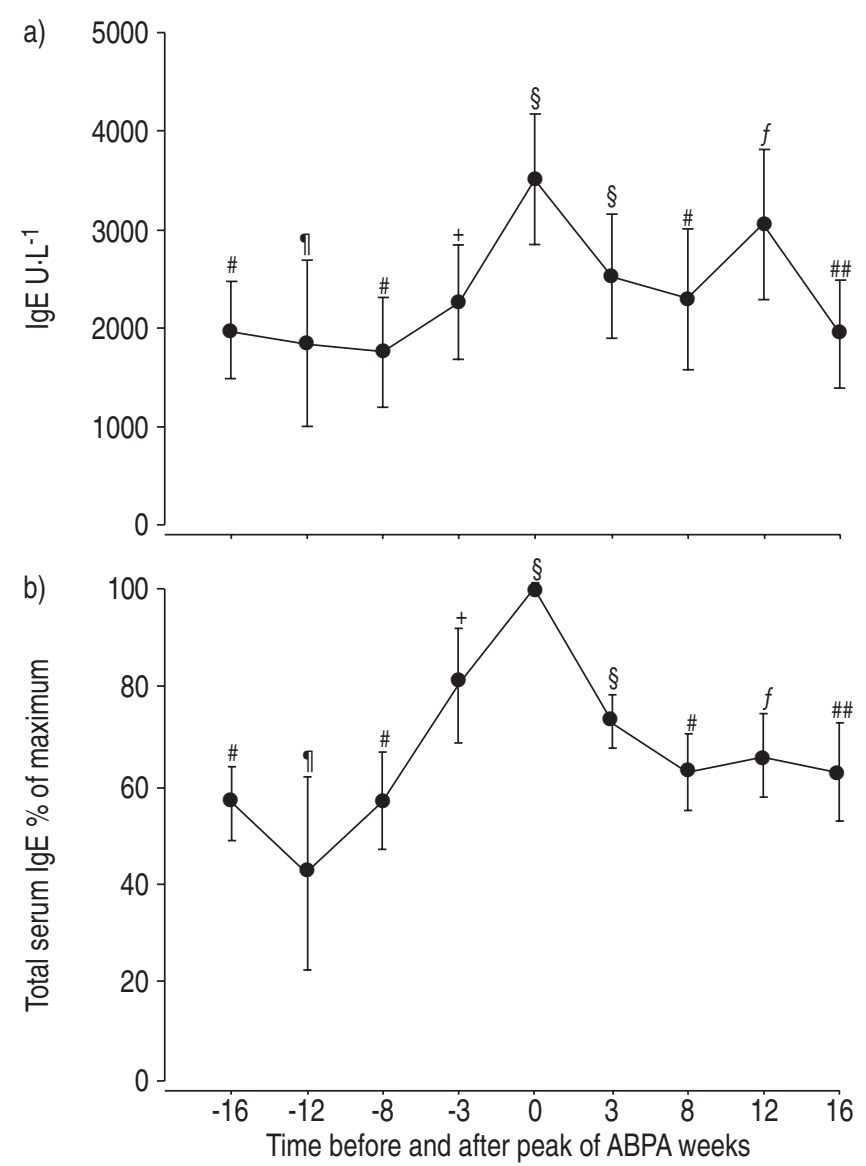

Fig. 1. - a) Serum immunoglobulin E (IgE) concentration (mean \pm SEM) during the course of an allergic bronchopulmonary aspergillosis (ABPA) episode. Data are given for the 16 weeks before and after the maximum of the total serum IgE concentration. b) The IgE concentration expressed as \% of the maximum IgE concentration for the same time period. Symbols indicate the number of data points. ${ }^{\#}$ : $7 ; \uparrow^{\circ}: 3 ;{ }^{+}: 2 ;$ § : $11 ;{ }^{f}: 5 ;{ }^{\# \#}: 6$.

The mean serum concentration of SP-D in CF patients with ABPA $\left(139 \pm 28 \mathrm{ng} \cdot \mathrm{mL}^{-1}\right)$ or without ABPA $\left(120 \pm 17 \mathrm{ng} \cdot \mathrm{mL}^{-1}\right)$ was higher than that of the patients without any evidence for a lung disease $\left(66 \pm 8 \mathrm{ng} \cdot \mathrm{mL}^{-1}\right)$ (fig. 4). CF-patients without ABPA had similar values to CF-patients with ABPA. The value for the CF patients with ABPA was calculated from the SP-D values at the peak of the serum $\operatorname{IgE}$ and was not different from the mean SP-D concentration of all data points in these group $\left(118 \pm 9 \mathrm{ng} \cdot \mathrm{mL}^{-1}\right)$. There was no correlation between body mass index of the CF patients and the level of SP-D.

\section{Discussion}

There was no significant change of the SP-D concentration in serum during an ABPA episode in CF patients. However, a correlation was found between a high serum level of SP-D and impaired lung function and there was a significant difference of the SP-D level between patients with CF and patients without pulmonary disease.

Unfortunately, from the results of the current study, SP-D does not appear to be useful for the diagnosis or management of ABPA in CF patients. Due to a general lack of clear-cut and easy to use serological markers for the diagnosis and management of ABPA, novel variables are highly desirable. The authors selected SP-D as a potential candidate, as
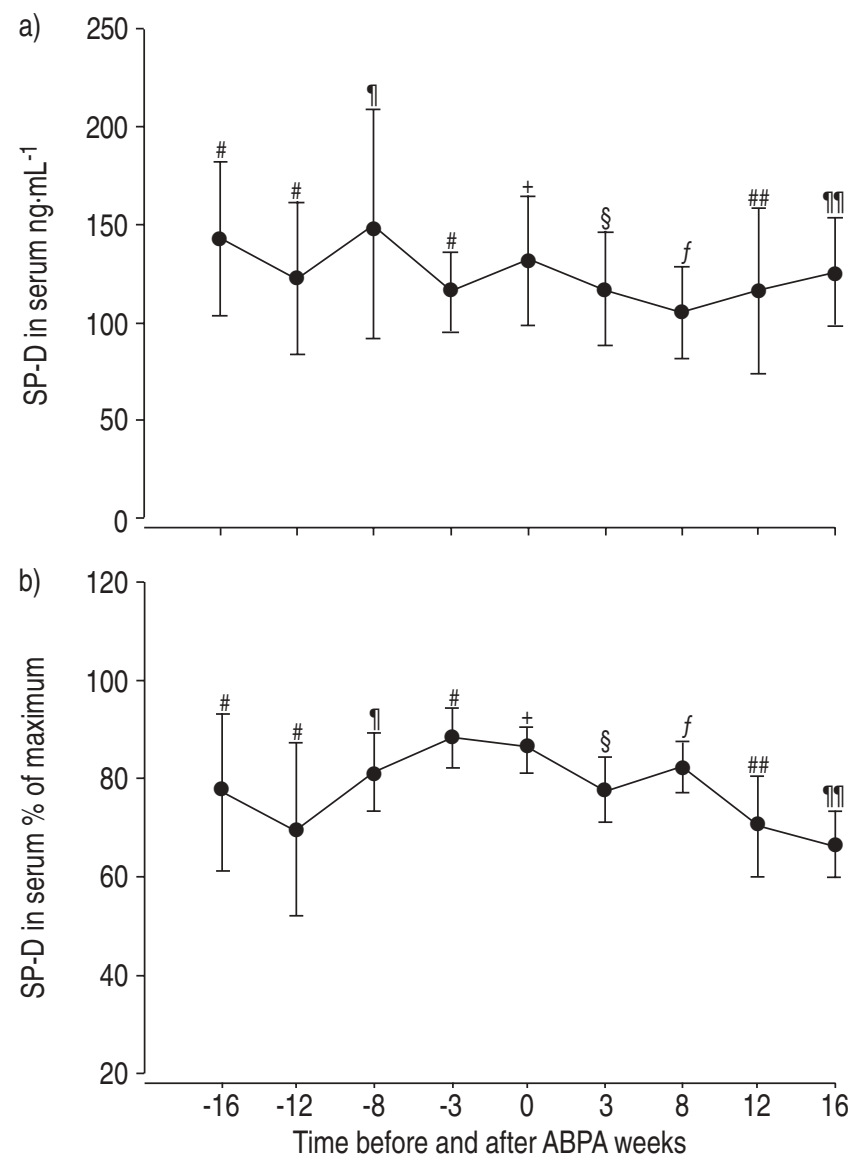

Fig. 2. - a) Serum surfactant protein D (SP-D) concentration (mean \pm SEM) during the course of an allergic bronchopulmonary aspergillosis (ABPA) episode. Data are given for the 16 weeks before and after the peak of an ABPA episode, defined by the peak of total serum immunoglobulin E levels. b) SP-D concentration (mean \pm SEM) expressed as $\%$ of the maximum SP-D concentration for the same time period. Symbols indicate the number of data points. ${ }^{\#}: 3 ;{ }^{\uparrow}: 5 ;{ }^{+}: 8 ;{ }^{\S}: 11$; f: $9 ;{ }^{\# \#: ~} 4 ;{ }^{\top \uparrow: ~} 6$.

HACZKU et al. [9] found strongly increased SP-D levels in the lavage during an $A$. fumigatus-induced allergic airway inflammation in $\mathrm{BALB} / \mathrm{c}$ mice. Several reasons may account for this finding. One may be the assessment of the SP-D level in the lavage and not in serum. Even a several-fold increase of SP-D concentration in the pulmonary compartment may not necessarily be linked to proportional increases in systemic circulation. However, in patients with alveolar proteinosis who have elevated pulmonary levels of SP-D, serum levels of SP-D are also increased [12]. In most cases the ABPA is a complication of chronic respiratory diseases, which lead to structural and functional changes. In the animal model, the induced allergic reaction was set in healthy mice without any changes caused by a chronic respiratory disease. The chronic respiratory infection in the airways of the $\mathrm{CF}$ patients may result in an altered regulation of SP-D expression, i.e. from the permanent presence of LPS or other bacterial signals [5]. Thus the stimuli associated with an ABPA in humans may not induce the same changes in SP-D level, as observed in model systems lacking a chronic bacterial lung injury and inflammation. These and other differences between the animal model and the human disease may be responsible for the different observation in the current study.

In serum the SP-D level is increased in patients with idiopathic pulmonary fibrosis, interstitial pneumonia with 

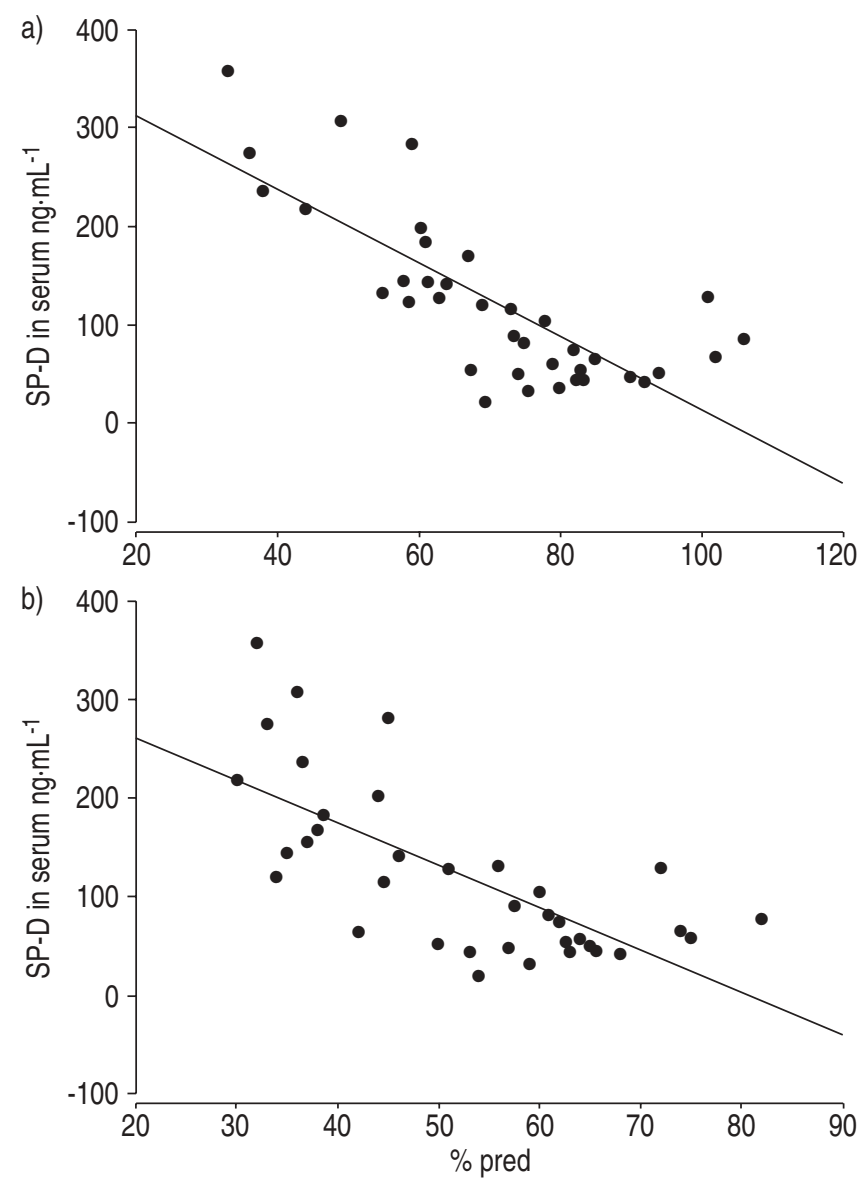

Fig. 3.-Correlation between the surfactant protein D (SP-D) concentration in serum and a) the forced vital capacity $(\mathrm{r}=0.78 ; \mathrm{p}<0.001)$ and $b)$ the forced expiratory volume in one second $(\mathrm{r}=0.70 ; \mathrm{p}<0.001)$ in 11 cystic fibrosis patients with allergic bronchopulmonary aspergillosis assessed in 36 instances. $\%$ pred: $\%$ predicted.

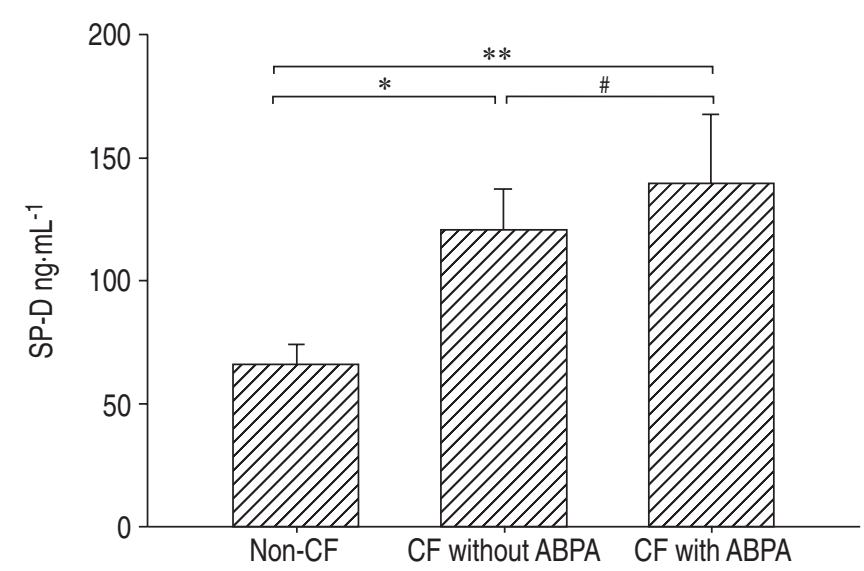

Fig. 4. - Average concentrations (mean \pm SEM) of surfactant protein $D$ (SP-D) in serum of 19 non-cystic fibrosis (CF) patients and $11 \mathrm{CF}$ patients with and 11 without allergic bronchopulmonary aspergillosis (ABPA). Comparison between the three groups were made by analysis of variance (overall $\mathrm{p}=0.0054$ ), followed by Newman-Keuls multiple comparison test. *: $\mathrm{p}<0.05 ;{ }^{* *}: \mathrm{p}<0.01 ; \#: \mathrm{p}>0.05$.

collagen vascular disease and pulmonary alveolar proteinosis, as mentioned above [12-13]. Here the authors were able to show the same for both groups of CF patients, with or without ABPA, in comparison to the group without $\mathrm{CF}$.
In particular in patients with a poor lung function, SP-D was increased. Whereas the relatively small changes of lung function during the course of the ABPA in individual patients was not reflected in changes of their SP-D serum concentrations, there was a clear inverse relation between the serum level of SP-D and (chronically) reduced FEV1 or FVC. This may suggest increased leakage of SP-D into the peripheral circulation or also increased production by the lungs, as none of the patients had systemic signs of ongoing inflammation, e.g. chronically increased level of total serum $\mathrm{IgG}$ or $\mathrm{C}$ reactive protein. The level of SP-D may be a valuable variable to assess lung injury and should be assessed in future studies, e.g. as potential marker for the disease activity.

In conclusion, surfactant protein $\mathrm{D}$ may be useful to follow pulmonary function and lung injury in cystic fibrosis patients, but does not appear helpful for the diagnosis of allergic bronchopulmonary aspergillosis in cystic fibrosis patients.

\begin{abstract}
Acknowledgements. The authors would like to thank the Yamasa Corporation (Choshi-city, Japan) and A. Nagata as a collaborate supporter, for their helpful support.
\end{abstract}

\section{References}

1. Wark PA, Gibson PG. Allergic bronchopulmonary aspergillosis: New concepts of pathogenesis and treatment. Respirology 2001; 6: 1-7.

2. Cockgrill BA, Hales CA. Allergic bronchopulmonary aspergillosis. Annu Rev Med 1999; 50: 303-316.

3. Skov M, Poulsen LK, Koch C. Increased antigen-specific TH-2 response in allergic bronchopulmonary aspergillosis (ABPA) in patients with cystic fibrosis. Pediatr Pulmonol 1999; 27: 74-79.

4. Khan S, McClellan JS, Knutsen AP. Increased sensitivity to IL-4 in patients with allergic bronchopulmonary aspergillosis. Int Arch Allergy Immunol 2000; 123: 319-326.

5. Crouch EC. Surfactant protein D and pulmonary host defense. Respir Res 2000; 1: 93-108.

6. Madan T, Kishore U, Shah A, et al. Lung surfactant proteins $A$ and $D$ can inhibit specific IgE binding to the allergens of Asp and block allergen-induced histamine release from human basophils. Clin Exp Immunol 1997; 110: 241-249.

7. Madan $\mathrm{T}$, Eggleton $\mathrm{P}$, Kishore $\mathrm{U}$, et al. Binding of pulmonary surfactant proteins A and D to Asp conidia enhances phagocytosis and killing by human neutrophils and alveolar macrophages. Infect Immun 1997; 65: 3171-3179.

8. Madan T, Kishore U, Singh M, et al. Surfactant proteins A and $\mathrm{D}$ protect mice against pulmonary hypersensitivity induced by Aspergillus fumigatus antigens and allergens. $J$ Clin Invest 2001; 107: 467-475.

9. Haczku A, Atochina EN, Tomer Y, et al. Aspergillus fumigatus-induced allegic airway inflammation alters surfactant homeostasis and lung function in BALB/c mice. $A m J$ Respir Cell Mol Biol 2001; 25: 45-50.

10. Nelson LA, Callerame ML, Schwartz RH. Aspergillosis and atopy in cystic fibrosis. Am Rev Respir Dis 1979; 120: 863873.

11. Nagae H, Takahashi H, Kuroki Y, et al. Enzyme-linked immunosorbent assy using $\mathrm{F}(\mathrm{ab})_{2}$ fragment for the detection of human pulmonary surfactant protein D in sera. Clin Chim Acta 1997; 266: 157-171.

12. Kuroki Y, Takahashi H, Chiba H, Akino T. Surfactant proteins A and D: disease markers. Biochim Biophys Acta 1998; 1408: 334-345.

13. Takahashi H, Kuroki Y, Tanaka H, et al. Serum levels of surfactant proteins $\mathrm{A}$ and $\mathrm{D}$ are useful biomarkers for interstitial lung disease in patients with progressive systemic sclerosis. Am J Respir Crit Care Med 2000; 162: 258-263. 